\title{
Effects of Feeding Frequency on Growth Performance, Antioxidant Status and Disease Resistance of Juvenile Red Swamp Crayfish, Procambarus clarkia
}

\author{
Jin-Juan Wan, Mei-Fang Shen*, Hui Xue, Hong-Yan Liu, Mei-Qin Zhang, \\ Xi-He Zhu and Chong-Hua Wang
}

Freshwater Fisheries Research Institute of Jiangsu Province, Nanjing 210017, China

\begin{abstract}
A B S T R A C T
This study was aimed to evaluate the effects of feeding frequency on growth performance, antioxidant status and immunity of juvenile red swamp crayfish Procambarus clarkia (average weight: $3.01 \pm 0.02$ g). Crayfish were randomly assigned to one of five feeding frequencies $(1,2,3,4$ and 5 times/day, F1, F2, F3, F4 and F5) following the same ration size for 60 days. After the feeding trial, fish were challenged with white spot syndrome virus (WSSV) and cumulative mortality was recorded for the next 4 days. The results showed that the weight gain rate (WGR) of crayfish tended to increase initially and then decrease as feeding frequency increased. The WGR in F3 were significantly higher than those fed 1, 4 and 5 times/ day $(P<0.05)$. The highest serum lysozyme (LZM), lowest catalase (CAT) and malondialdehyde (MDA) were observed in crayfish fed 3 times/day. However, there were no significant differences in cortisol, glucose (Glu), and superoxide dismutase (SOD) among all groups $(P>0.05)$. The cumulative mortality in F3 was significantly lower than that of the other groups at $\mathrm{d} 4$ after challenge $(P<0.05)$. In conclusion, both low and high feeding frequencies could cause stress of juvenile Procambarus clarkia and the optimal feeding frequency to enhance growth and immunity of this species at juvenile stage is 3 times/day.
\end{abstract}

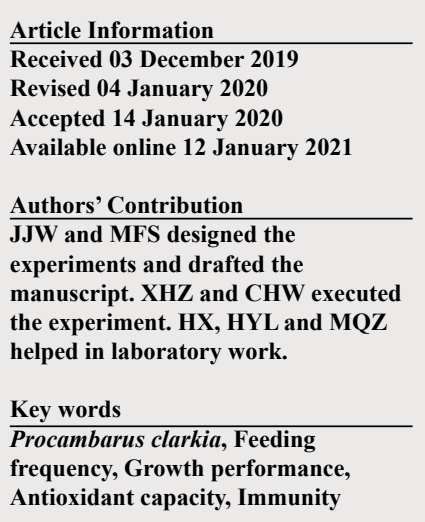

Article Information

Accepted 14 January 202

Available online 12 January 202

Authors' Contribution

experim and MFS designed the manuscript. XHZ and $\mathrm{CHW}$ executed

the experiment. HX, HYL and MQZ

helped in laboratory work.

\section{INTRODUCTION}

$\mathrm{T}$ he growth and physiology of fish is largely influenced by a number of factors, such as the quantity and quality of feed, feeding frequency, feed intake and its ability to absorb nutrients (Hakim et al., 2006; Xie et al., 2011; Wan et al., 2017). Besides, feed is generally the highest variable costs during aquaculture, appropriate feeding strategies can improve growth and reduce waste. In one word, feed practice is vital in aquaculture. Among these, feeding frequency plays an important role in feeding strategy (Zhou et al., 2003). The optimal feeding frequency not only increase profits, reduces size variation, but also decrease production costs and minimize water pollution (Wang et al., 2007; Villarroel et al., 2011; Liang and Chien, 2013). Most of the previous studies have focused on the influence of feeding frequency on growth performance and feed intake during the last decades (Wang et al., 1998; Booth et al., 2008; Biswas et al., 2010). Nowadays more and more attention is being paid to its potential effects on immunity and stress response due to the fact that the health and welfare of

\footnotetext{
Corresponding author: mfshen2015@163.com 0030-9923/2021/0002-0474 \$ 9.00/0

Copyright 2021 Zoological Society of Pakistan
}

aquatic animals is tightly regulated by feeding regimes (Li et al., 2014; Russo et al., 2017). White spot syndrome virus (WSSV) is the type species of the genus Whispovirus in the family Nimaviridae (Sánchez-Martínez et al., 2007; Escobedo-Bonilla et al., 2008). With the capability to infect a wide range of crustaceans, including shrimp, crab and crayfish, WSSV is at present a major scourge to shrimp cultivation and has caused great economic loss in aquaculture industry worldwide since 1990s (Chou et al., 1995; Lo et al., 1996; Van Hulten et al., 2001). Up to date, there is lack of effective strategies against WSSV infection (Dai et al., 2016). The studies of WSSV replication and host-interactions would help to explore effective strategies for WSSV prevention and control.

The red swamp crayfish Procambarus clarkii is one of the most important and widespread freshwater crayfish in Chinese inland because of its flavor, increasing commercial benefits, excellent disease resistance against pathogens and high tolerance to environment changes $(\mathrm{Bi}$ et al., 2008; Wang et al., 2009; Ou et al., 2013). In China, the annual aquaculture production was over 1000,000 tons in 2018 (Yearbook CFS, 2019). At present very little information is available on feeding frequency in red swamp crayfish, which seriously restricts the sustainable development of this species under intensive culture. The 
objective of this study, therefore, was to investigate the effects of feeding frequency on growth, stress response, oxidative status and immunity of juvenile red swamp crayfish.

\section{MATERIALS AND METHODS}

\section{Crayfish and test diets}

Red swamp crayfish were obtained from Lukou fish farm of Freshwater Fisheries Research Institute of Jiangsu province, Nanjing, China. Prior to the study, crayfish were reared in outdoor tank $(2.5 \mathrm{~m} \times 2.5 \mathrm{~m} \times 0.8 \mathrm{~m}, \mathrm{~L}$ : W: $\mathrm{H}$, water height: $0.2 \mathrm{~m}$ ) for 2 weeks to acclimate to the experimental conditions. During this period, the tanks were supplied with aerated recycled water, all crayfish were fed with test diet once per day (19:00) at a feeding rate of $4 \%$ whole body weight. After the conditioning period, 750 crayfish (initial body weight $3.01 \pm 0.02 \mathrm{~g}$ ) were randomly distributed into 15 outdoor rectangular tanks $(2.5 \mathrm{~m} \times 2.5 \mathrm{~m} \times 0.8 \mathrm{~m}$, water height: $0.2 \mathrm{~m} ; 50$ crayfish per tank) with floating underground water. A total of $10 \mathrm{PVC}$ tubes of $30 \mathrm{~cm}$ length were placed in each tank to reduce the aggressive interaction among crayfish.

Table I. Formulation and proximate composition of the experimental diet (\%, Dry matter basis).

\begin{tabular}{llll}
\hline Ingredients & Content $\begin{array}{l}\text { Nutritional } \\
\text { composition }\end{array}$ & Content \\
\hline Fish meal & 10 & Crude protein & 28.97 \\
Soybean meal & 25 & Crude lipid & 5.66 \\
Rapeseed meal & 12 & Ash & 5.6 \\
Peanut meal & 12 & Gross energy(MJ/kg) & 17.32 \\
Flour & 22 & & \\
Rice bran & 6 & & \\
Soybean oil & 2 & & \\
Ecdysone premix & 0.15 & & \\
Shrimp shell meal & 3 & & \\
Calcium biphosphate & 2.85 & \\
Squid paste & 4 & \\
Premix & 1 & \\
Total & 100 & & \\
\hline
\end{tabular}

Note: 1. Premix (per kg diet): VE $150 \mathrm{mg}$, VK $50 \mathrm{mg}$, thiamine $80 \mathrm{mg}$, riboflavin $50 \mathrm{mg}$, Niacin $150 \mathrm{mg}$, pantothenic acid $150 \mathrm{mg}$, pyridoxine $50 \mathrm{mg}$, biotin $1 \mathrm{mg}$, cyanocobalamin, $0.02 \mathrm{mg}$, folic acid $10 \mathrm{mg}$, VC 300 IU, VA $10000 \mathrm{IU}$, VD $2000 \mathrm{IU}$, copper sulphate $2.0 \mathrm{~g}$, iron sulphate 25 $\mathrm{g}$, zinc sulphate $22 \mathrm{~g}$, manganese sulphate $7 \mathrm{~g}$, sodium selenite $0.04 \mathrm{~g}$, potassium iodide $0.026 \mathrm{~g}$, cobalt chloride $0.1 \mathrm{~g}$.

Test diets were produced at the Nanjing Shuaifeng feed co., LTD, Nanjing, China. The diets were formulated to contain approximately $28.97 \%$ crude protein and $5.66 \%$ crude lipid according to the previous research (Xu et al., 2013), the diets formulation and composition were showed in Table I. Crayfish were fed at a ration of $4 \%$ of the total body weight per day, and feed amount was adjusted once every two weeks based on its growth rate to ensure that all feed was eaten.

\section{Experimental design}

The experiment design included five feeding frequencies (1, 2, 3, 4, 5 times throughout the day: F1, F2, F3, F4 and F5) with three replicates for each treatment. The feeding frequency and time followed in different treatments are presented in Table II.

During the rearing period, the mean water quality indices were: water temperature ranged from $28^{\circ} \mathrm{C}$ to 31 ${ }^{\circ} \mathrm{C}, \mathrm{DO}>6.85 \mathrm{mg} / \mathrm{L}, \mathrm{NH}_{3}<0.039 \mathrm{mg} / \mathrm{L}, \mathrm{H}_{2} \mathrm{~S}<0.015 \mathrm{mg} / \mathrm{L}$, and $\mathrm{pH}$ 6.6 7.6, and crayfish were exposed to alternating 12 -h light and dark periods. The exuvial and dead crayfish were checked daily. After 60 days, crayfish from each tank were counted and weighed.

Table II. Daily feeding frequency and time for Red swamp crayfish during the feeding trial.

\begin{tabular}{ll}
\hline $\begin{array}{l}\text { Feeding frequency } \\
\text { (times/day) }\end{array}$ & Feeding time \\
\hline 1 & $19: 00$ \\
2 & $07: 00$ and 19:00 \\
3 & $07: 00,13: 00$ and $19: 00$ \\
4 & $07: 00,11: 00,15: 00$ and 19:00 \\
5 & $07: 00,11: 00,15: 00,19: 00$ and $23: 00$ \\
\hline
\end{tabular}

WSSV challenge test

Preparation of WSSV inoculum

The WSSV-infected P. clarkia were collected from local crayfish farms. Muscle and gills were obtained and centrifuged at $3000 \mathrm{r} / \mathrm{min}$ for $20 \mathrm{~min}$ at $4{ }^{\circ} \mathrm{C}$, the supernatant was filtered through a $0.22 \mu \mathrm{m}$ membrane filter. The filtrate was saved for WSSV challenge experiment.

\section{WSSV challenge experiment}

After the initial sampling, 10 crayfish with similar body weight obtained from each tank were moved to a new plastic tank $(1.0 \mathrm{~m} \times 0.4 \mathrm{~m} \times 0.4 \mathrm{~m}$, height of water $0.1 \mathrm{~m})$ and allowed to acclimate for 2 days before the challenge. The WSSV was obtained from Freshwater Fisheries Research Institute (Nanjing, China). All crayfish were injected intramuscularly with $0.1 \mathrm{ml}$ WSSV suspension using medical syringes (Zhang et al., 2012). The dead crayfish were recorded and removed from each tank for 4 
days, the cumulative mortality of each tank was counted at $0,1,2,3,4 \mathrm{~d}$ after infection. During the challenge period, the experimental conditions and diets were the same as those in the feeding trial.

\section{Sampling and processing}

At termination of the feeding trial, crayfish were starved for $24 \mathrm{~h}$ to evacuate the alimentary tract contents prior to weighing and sampling. Hemolymph was obtained with a syringe from 9 crayfish in each tank, following centrifugation $\left(5000 \mathrm{r} / \mathrm{min}, 10 \mathrm{~min}, 4{ }^{\circ} \mathrm{C}\right)$, the supernatant was removed and frozen at $-80^{\circ} \mathrm{C}$ for analysis of serum glucose, cortisol, lysozyme and antioxidant capacity.

\section{Analysis and measurement}

The level of glucose, cortisol, lysozyme, superoxide dismutase (SOD), malondialdehyde (MDA) and catalase (CAT) were measured by Nanjing Jiancheng Bioengineering Institute (Nanjing, China).

The growth parameter in this study was calculated as follows:

Weight gain rate $($ WGR, \% $)=100 \times($ final body weightinitial body weight) / initial body weight

Feed conversion ratio $(\mathrm{FCR})=$ feed intake /weight gain
Survival rate $(\mathrm{SR}, \%)=100 \times$ final number of crayfish/ initial number of crayfish

Data statistics and analysis

Data were subjected to one-way analysis of variance (ANOVA) using the SPSS programme version 19.0 (SPSS Inc., Michigan Avenue, Chicago, IL, USA) for Windows. If significant $(P<0.05)$ differences were found, Duncan's multiple range test was used to rank the means. Results were expressed by mean \pm SEM of the replicate groups ( 3 tanks per treatment; $n=3$ ).

\section{RESULTS}

Growth performance

As can be seen from Table III, the weight gain rate (WGR) of crayfish tended to increase at first and then decrease as feeding frequency increased, the feed conversion ratio (FCR) showed an opposite tendency among the treatments. The WGR of crayfish fed 3 times/ day was significantly higher than crayfish fed 1, 4 and 5 times/day, the FCR of crayfish fed 2 and 3 times/day were significantly lower than those fed 1 and 5 times/ day $(P<0.05)$. Survival rate showed no significantly difference among all the treatments $(P>0.05)$.

Table III. Effects of feeding frequency on growth performance of juvenile Procambarus clarkia.

\begin{tabular}{llllll}
\hline $\begin{array}{l}\text { Feeding fre- } \\
\text { quency }\end{array}$ & $\begin{array}{l}\text { Initial body } \\
\text { weight } \mathbf{( g )}\end{array}$ & $\begin{array}{l}\text { Final body } \\
\text { weight } \mathbf{( g )}\end{array}$ & $\begin{array}{l}\text { Weight gain } \\
\text { rate (\%) }\end{array}$ & $\begin{array}{l}\text { Feed conversion } \\
\text { ratio }\end{array}$ & Survival rate (\%) \\
\hline F1 & $3.01 \pm 0.00$ & $30.18 \pm 1.28^{\mathrm{a}}$ & $899.84 \pm 43.11^{\mathrm{a}}$ & $0.90 \pm 0.04^{\mathrm{b}}$ & $87.33 \pm 1.15$ \\
F2 & $3.01 \pm 0.02$ & $32.73 \pm 0.12^{\mathrm{b}}$ & $997.94 \pm 12.87^{\mathrm{bc}}$ & $0.81 \pm 0.00^{\mathrm{a}}$ & $86.00 \pm 2.00$ \\
F3 & $3.02 \pm 0.00$ & $33.94 \pm 1.05^{\mathrm{b}}$ & $1058.72 \pm 33.24^{\mathrm{c}}$ & $0.75 \pm 0.03^{\mathrm{a}}$ & $85.33 \pm 1.15$ \\
F4 & $3.03 \pm 0.00$ & $31.98 \pm 2.10^{\mathrm{a}}$ & $961.93 \pm 25.36^{\mathrm{b}}$ & $0.83 \pm 0.07^{\mathrm{ab}}$ & $84.00 \pm 5.29$ \\
F5 & $3.01 \pm 0.01$ & $29.34 \pm 2.50^{\mathrm{a}}$ & $869.31 \pm 22.06^{\mathrm{a}}$ & $0.96 \pm 0.07^{\mathrm{b}}$ & $83.00 \pm 5.62$ \\
\hline
\end{tabular}

Notes: Values as mean \pm S.E. of three replicate tanks and values within the same row with different superscript letters are significantly different (Duncan's multiple-range test, $P<0.05$ ).

Table IV. Effects of feeding frequency on anti-stress capacity and antioxidant enzymes activities of juvenile Procambarus clarkia.

\begin{tabular}{lllllll}
\hline $\begin{array}{l}\text { Feeding fre- } \\
\text { quency }\end{array}$ & $\begin{array}{l}\text { Glucose } \\
(\mathbf{m m o l} / \mathbf{L})\end{array}$ & $\begin{array}{l}\text { Cortisol } \\
(\mathbf{n g} / \mathbf{m l})\end{array}$ & $\begin{array}{l}\text { Lysozyme } \\
(\mathbf{n g} / \mathbf{m l})\end{array}$ & $\begin{array}{l}\text { Superoxide } \\
\text { dismutase } \mathbf{( U / m l})\end{array}$ & $\begin{array}{l}\text { Catalase } \\
\mathbf{( U / m l )}\end{array}$ & $\begin{array}{l}\text { Malondialdehyde } \\
(\mathbf{n m o l} / \mathbf{m l})\end{array}$ \\
\hline F1 & $1.5 \pm 0.07$ & $46.7 \pm 1.10$ & $36.9 \pm 4.44^{\mathrm{a}}$ & $51.44 \pm 0.58$ & $1.24 \pm 0.07^{\mathrm{b}}$ & $1.79 \pm 0.07^{\mathrm{c}}$ \\
F2 & $1.4 \pm 0.04$ & $45.6 \pm 0.45$ & $33.8 \pm 4.44^{\mathrm{a}}$ & $51.16 \pm 0.37$ & $1.14 \pm 0.09^{\mathrm{b}}$ & $1.78 \pm 0.08^{\mathrm{c}}$ \\
F3 & $1.5 \pm 0.17$ & $47.1 \pm 2.88$ & $71.8 \pm 8.88^{\mathrm{c}}$ & $52.46 \pm 1.43$ & $0.81 \pm 0.03^{\mathrm{a}}$ & $1.45 \pm 0.06^{\mathrm{a}}$ \\
F4 & $1.5 \pm 0.07$ & $46.3 \pm 2.05$ & $49.2 \pm 4.44^{\mathrm{b}}$ & $53.40 \pm 1.71$ & $0.76 \pm 0.04^{\mathrm{a}}$ & $1.56 \pm 0.09^{\mathrm{b}}$ \\
F5 & $1.4 \pm 0.16$ & $43.0 \pm 0.98$ & $53.8 \pm 7.69^{\mathrm{b}}$ & $58.46 \pm 1.13$ & $1.07 \pm 0.09^{\mathrm{b}}$ & $1.67 \pm 0.07^{\mathrm{bc}}$ \\
\hline
\end{tabular}

Notes: Values as mean \pm S.E. of three replicate tanks and values within the same row with different superscript letters are significantly different (Duncan's multiple-range test, $P<0.05$ ). 
Stress response and oxidative status

Parameters indicating the stress response and oxidative status of red swamp crayfish are presented in Table IV. Serum lysozyme (LZM) levels were significantly higher in crayfish fed with 3 times/day; serum catalase (CAT) levels were significantly lower in crayfish fed with 3 and 4 times/day; crayfish fed 3 times/day had the lowest malondialdehyde (MDA) $(P<0.05)$. Serum glucose, cortisol and superoxide dismutase (SOD) levels did not differ significantly among the groups $(P>0.05)$.

\section{Cumulative mortality after challenge}

As can be seen from Figure 1, after WSSV challenge, the cumulative mortality of crayfish tended to decrease at first and then increase as feeding frequency increased. The crayfish were succumbed to death started from $2^{\text {nd }}$ day of challenge test. The cumulative mortality in crayfish fed 5 times/day was significantly higher than other treatments at 2 days after challenge $(P<0.05)$. The cumulative mortality in crayfish fed 2 and 3 times/day were significantly lower than crayfish fed 1, 4 and 5 times/day at 3 days after challenge $(P<0.05)$, and by day 4 , crayfish fed 3 and 5 times/day had the lowest and highest cumulative mortality respectively $(P<0.05)$, the difference among $\mathrm{F} 1, \mathrm{~F} 2$ and F4 was not significant $(P>0.05)$.

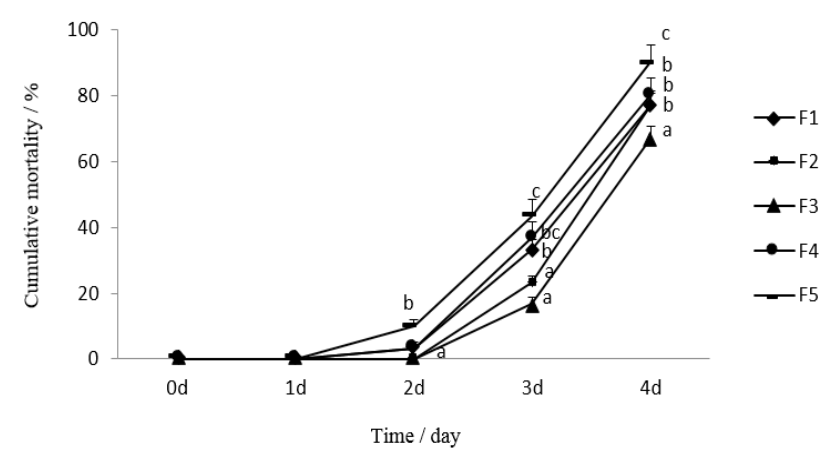

Fig. 1. Effects of feeding frequency on cumulative mortality of juvenile procambarus clarkia challenged with white spot syndrome virus. Values as mean \pm S.E. of three replicate thanks and values whitin the same row with different superscript letters are significantly different (Duncan's multiple-range test, $P<0.05$ ).

\section{DISCUSSION}

In this study, feeding frequency had significant effects on growth performance and feed consumption in juvenile red swamp crayfish. Crayfish fed 3 times/day had the highest WGR, which was significantly higher than those fed 1, 4 and 5 times/day; furthermore, the FCR was the lowest when crayfish were fed 3 times/day, while further increases in feeding frequency did not lead to an improvement in feed utilization. This suggested that both low and high feeding frequencies could attenuate the growth rate and feed utilization of juvenile Procambarus clarkia. Previous studies carried out on Limanda ferruginea, Platichthys flesus luscus and Megalobrama amblycephala have also demonstrated that growth and feed consumption increased linearly with an increase in the feeding frequency up to a certain level (Dwyer et al., 2002; Küçük et al., 2014; Tian et al., 2015). This might be due to the fact that crayfish in each group were offered the same ration size, when the intervals between meals is short, the food passes through the digestive tract more quickly, resulting in less effective digestion (Riche et al., 2004; Biswas et al., 2010; Zhao et al., 2016). In addition, increasing feeding intervals all day long can increase swimming activity of fish, leading to energy expenditure and lower growth rate (Johansen and Jobling, 1998). Contrary to the finding of this study, Okomoda et al. (2019) reported that the increasing feeding frequency resulted in an increase in growth up to six rations daily, although the performance was largely the same beyond five rations a day frequency. This was because effect of feeding frequency could differ by the age of animal.

In the present experiment, serum glucose and cortisol levels did not differ significantly among the groups. However, CAT activities decrease at first and then increase as feeding frequency increased, a similar trend was also observed in MDA activities. CAT plays an important role in the self-defense system and antioxidant defense pathways as an antioxidant enzyme, However, MDA, the main component of lipid peroxides, has a strong biotoxicity and will damage the cell structure and function (Freeman and Crapo, 1982). This indicated that both low and high feeding frequencies might cause oxidative stress response of juvenile Procambarus clarkia. The observations are consistent with the results obtained by $\mathrm{Li}$ et al. (2014) who reported that feeding frequency very often affects the oxidative status of juvenile blunt snout bream; Guo et al. (2018) also indicated that both low and high feeding frequencies might cause oxidative stress of juvenile dolly varden char. It might be related to the alteration of the physiological state of crayfish subjected to sub-optimal conditions, and then inevitably resulted in an imbalance between the generation and removal of reactive oxygen species (ROS), as consequently produced oxidative stress (Lygren et al., 1999; Dabas et al., 2012).

Lysozyme level is an important index of innate immunity of aquatic animal. It is well documented that lysozyme possess lytic activity against both Gram-positive bacteria and Gram-negative bacteria (Saurabh and Sahoo, 2008). Lysozyme activity has been shown to vary depending on the nutrition, season and water quality (Dominguez et 
al., 2005; Kumari and Sahoo, 2006; Yildiz, 2006; Swain et al., 2007). In this experiment, the serum lysozyme level increased significantly as feeding frequency increased from 1 to 3 times per day but decreased significantly with further increasing feeding frequencies. Since nutritional support plays an important role in maintaining optimum health conditions of organism (Kumar et al., 2005; Saurabh and Mohanta, 2006), the present results indicate an immunosuppression of crayfish subjected to suboptimal feeding frequencies. This is supported by Li et al. (2014) in juvenile blunt snout bream (Megalobrama amblycephala) fed both low and high feeding frequencies which caused the depressed immunity. Furthermore, the depressed immunity of crayfish under suboptimal feeding frequencies was supported by the relatively high cumulative mortality after WSSV challenge.

WSSV has caused mass mortalities and devastating production losses to shrimp farming over many areas (Lightner, 1996). WSSV is known to infect many crustacean species, including crayfish (Shi et al., 2005; Zeng and Lu, 2009). Both farmed and wild Procambarus clarkii were natural hosts for WSSV (Baumgartner et al., 2009), and has caused high levels of mortality in crayfish, resulting into significant economic loss (Zhan et al., 1998; Yi et al., 2017). Based on present study, the cumulative mortality in crayfish fed 3 and 2 times/day were significantly lower than crayfish fed 1, 4 and 5 times/day after challenge, and by day 4, 5 times/day had the highest cumulative mortality. The results indicated that both low and high feeding frequencies cause stress response, which might consequently lead to the elevated liver oxidation rates and depressed immunity of this species. Based on previous studies, the suppressed immunity of fish subjected to high feeding frequencies might be ascribed to the relatively low lysozyme level and liver oxidation rates. This is based on the fact that lysozyme has immunosuppressive actions and oxidative stress usually makes fish more susceptible to diseases (Sheikhzadeh et al., 2012).

\section{CONCLUSION}

Results in the present study indicated that juvenile Procambarus clarkia can achieve maximum growth when they are fed a given ration three times a day. Low and high feeding frequencies not only produce poor growth performance and disease resistance, but may also induce oxidative stress response.

\section{ACKNOWLEDGEMENTS}

This research was supported by funding from the Jiangsu Agricultural Industry Technology System ( Red
Swamp Crayfish) (JATS [2019]387) and China Agriculture Research System (CARS-48).

\section{Conflict of interest and ethical statement}

We declare that we have no financial and personal relationships with other people or organizations that can inappropriately influence our work, there is no professional or other personal interest of any nature or kind in any product, service and/or company that could be construed as influencing the position presented in, or the review of, the manuscript entitled, "Effects of feeding frequency on growth performance, stress and disease resistance of juvenile red swamp crayfish, Procambarus clarkia".

\section{REFERENCES}

Baumgartner, W.A., Hawke, J.P., Bowles, K., Varner, P.W. and Hasson, K.W., 2009. Primary diagnosis and surveillance of white spot syndrome virus in wild and farmed crawfish (Procambarus clarkii, $P$. zonangulus) in Louisiana, USA. Dis. Aquat. Organ., 85: 15-22. https://doi.org/10.3354/dao02051

Bi, K., Gu, W. and Wang, W., 2008. Sensitive and rapid detection of freshwater crustacean Spiroplasmas by ISRs-sequence-targeted species-specific primers. Eur. Fd. Res. Technol., 227: 1733-1737. https://doi. org/10.1007/s00217-008-0903-1

Biswas, G., Thirunavukkarasu, A.R., Sundaray, J.K. and Kailasam, M., 2010. Optimization of feeding frequency of Asian seabass (Lates calcarifer) fry reared in net cages under brackishwater environment. Aquaculture, 305: 26-31. https://doi. org/10.1016/j.aquaculture.2010.04.002

Booth, M.A., Tucker, B.J., Allan, G.L. and Fielder, D.S., 2008. Effect of feeding regime and fish size on weight gain, feed intake and gastric evacuation in juvenile Australian snapper Pagrus auratus. Aquaculture, 282: 104-110. https://doi. org/10.1016/j.aquaculture.2008.06.027

Chou, H.Y., Huang, C.Y., Wang, C.H., Chiang, H.C. and Lo, C.F., 1995. Pathogenicity of a baculovirus infection causing white spot syndrome in cultured penaeid shrimp in Taiwan. Dis. Aquat. Organ., 23: 165-173. https://doi.org/10.3354/dao023165

Dabas, A., Nagpure, N.S., Kumar, R., Kushwaha, B., Kumar, P. and Lakra, W.S., 2012. Assessment of tissue-specific effect of cadmium on antioxidant defense system and lipid peroxidation in freshwater murrel, Channa punctatus. Fish Physiol. Biochem., 38: 469-482. https://doi.org/10.1007/s10695-0119527-7

Dai, Y.J., Wang, Y.G., Zhao, L.L., Qin, Z.D., Yuan, J.F., 
Qin, G.W., Lin, L. and Lan, J.F., 2016. A novel L-type lectin was required for the multiplication of WSSV in red swamp crayfish (Procambarus clakii), Fish Shellf. Immunol., 55: 48-55. https:// doi.org/10.1016/j.fsi.2016.05.020

Dominguez, M., Takemura, A. and Tsuchiya, M., 2005. Effects of changes in environmental factors on the non-specific immune response of Nile tilapia, Oreochromis niloticus L. Aquacul. Res., 36: 391-397. https://doi.org/10.1111/j.13652109.2005.01220.x

Dwyer, K.S., Brown, J.A., Parrish, C. and Lall, S.P., 2002. Feeding frequency affects food consumption, feeding pattern and growth of juvenile yellowtail flounder (Limanda ferruginea). Aquaculture, 213: 279-292. https://doi.org/10.1016/S00448486(02)00224-7

Escobedo-Bonilla, C.M., Alday-Sanz, V., Wille, M., Sorgeloos, P., Pensaert, M.B. and Nauwynck, H.J., 2008. A review on the mor- phology, molecular characterization, morphogenesis and pathogenesis of white spot syndrome virus. J. Fish Dis., 31: 1-18. https://doi.org/10.1111/j.1365-2761.2007.00877.x

Freeman, B.A. and Crapo, J.D., 1982. Biology of disease: free radicals and tissue injury. Lab. Investig., 47: 412-426.

Guo, Z.X., Cui, J.Y., Li, M., Liu, H.H., Zhang, M.Z., Meng, F.X., Shi, G., Wang, R.X., He, X.Y. and Zhao, Y.M., 2018. Effect of feeding frequency on growth performance, antioxidant status, immune response and resistance to hypoxia stress challenge on juvenile dolly varden char Salvelinus malma. Aquaculture, 486: 197-201. https://doi. org/10.1016/j.aquaculture.2017.12.031

Hakim, Y., Uni, Z., Hulata, G. and Harpaz, S., 2006. Relationship between intestinal brush border enzymatic activity and growth rate in tilapias fed diets containing $30 \%$ or $48 \%$ protein. Aquaculture, 257: $\quad 420-428 . \quad$ https://doi.org/10.1016/j. aquaculture.2006.02.034

Johansen, S.J.S. and Jobling, M., 1998. The influence of feeding regime on growth and slaughter traits of cagereared Atlantic salmon. Aquacul. Int., 6: 1-17.

Kumar, V., Saurabh, S., Sahu, N.P. and Pal, A.K., 2005. $\beta$-Glucan, a feed additive to manage aquatic animal health. Aqua Feeds: Formul. Beyond, 2: 9-11.

Kumari, J. and Sahoo, P.K., 2006. Dietary $\beta-1,3$ glucan potentiates innate immunity and disease resistance of Asian catfish, Clarias batrachus (L.). J. Fish Dis., 29: 95-101. https://doi.org/10.1111/j.13652761.2006.00691.x

Küçük, E., Aydın, İ., Polat, H., Eroldoğan, O.T. and
Şahin, T., 2014. Effect of feeding frequency on growth, feed efficiency and nutrient utilization of juvenile flounder (Platichthys flesus luscus). Aquacul. Int., 2: 723-732. https://doi.org/10.1007/ s10499-013-9701-2

Li, X.F., Tian, H.Y., Zhang, D.D., Jiang, G.Z. and Liu, W.B., 2014. Feeding frequency affects stress, innate immunity and disease resistance of juvenile blunt snout bream Megalobrama amblycephala. Fish Shellf. Immunol., 38: 80-87. https://doi. org/10.1016/j.fsi.2014.03.005

Liang, J.Y. and Chien, Y.H., 2013. Effects of feeding frequency and photoperiod on water quality and crop production in a tilapia-water spinach raft aquaponics system. Int. Biodeterior. Biodegrad., 85: 693-700. https://doi.org/10.1016/j. ibiod.2013.03.029

Lightner, D.V., 1996. A handbook of shrimp pathology and diagnostic procedures for diseases of cultured penaeid shrimp. World Aquatic Society. Baton Rouge, LA.

Lo, C.F., Ho, C.H., Peng, S.E., Chen, C.H., Hsu, H.C., Chiu, Y.L., Chang, C.F., Liu, K.F., Su, M.S., Wang, C.H. and Kou, G.H., 1996. White spot syndrome baculovirus (WSBV) detected in cultured and captured shrimp, crabs and other arthropods. Dis. Aquat. Org., 27: 215-225. https://doi.org/10.3354/ dao027215

Lygren, B., Hamre, K. and Waagbø, R., 1999. Dietary pro-and antioxidants and some health parameters in Atlantic salmon (Salmo salar). J. Aquat. Anim. Hlth., 11: 211-221. https://doi.org/10.1577/15488667(1999)011<0211:EODPAA >2.0.CO;2

Okomoda, V.T., Aminem, W., Hassan, A. and Martins, C.O., 2019. Effects of feeding frequency on fry and fingerlings of African catfish Clarias gariepinus. Aquaculture, 511: 734232. https://doi. org/10.1016/j.aquaculture.2019.734232

Ou, J.T., Li, Y., Ding, Z.F., Xiu, Y.J., Wu, T., Du, J., Li, W.J., Zhu, H.X., Ren, Q., Gu, W. and Wang, W., 2013. Transcriptome-wide identification and characterization of the Procambarus clarkii microRNAs potentially related to immunity against Spiroplasma eriocheiris infection. Fish Shellf. Immunol., 35(2): 607-617. https://doi. org/10.1016/j.fsi.2013.05.013

Riche, M., Oetker, M., Haley, D.I., Smith, T. and Garling, D.L., 2004. Effect of feeding frequency on consumption, growth, and efficiency in juvenile Nile tilapia (Oreochromis niloticus). Isr. J. Aquacult-Bamid., 56: 247-255.

Russo, D.J., Watanabe, W.O., Kinsey, S.T. and Seaton, 
P.J., 2017. Effects of feeding frequency of live prey on larval growth, survival, resistance to hyposalinity stress, $\mathrm{Na}^{+} / \mathrm{K}^{+}$ATPase activity and fatty acid profiles in black sea bass Centropristis striata. Aquaculture, 470: 56-67. https://doi. org/10.1016/j.aquaculture.2016.12.005

Sánchez-Martínez, J.G., Aguirre-Guzmán, G. and Mejía-Ruíz, H., 2007. White spot syndrome virus in cultured shrimp: A review. Aquacult. Res., 38: 1339-1354. https://doi.org/10.1111/j.13652109.2007.01827.x

Saurabh, S. and Mohanta, K.N., 2006. Nutritional disorders of fishes with a special reference to ornamental fish: An overview. Aquacul. Int., 14: 31-34.

Saurabh, S. and Sahoo, P.K., 2008. Lysozyme: an important defence molecule of fish innate immune system. Aquacul. Res., 39: 223-239. https://doi. org/10.1111/j.1365-2109.2007.01883.x

Sheikhzadeh, N., Tayefi-Nasrabadi, H., Oushani, A.K. and Enferadi, M.H.N., 2012. Effects of Haematococcus pluvialis supplementation on antioxidant system and metabolism in rainbow trout (Oncorhynchus mykiss). Fish Physiol. Biochem., 38: 413-419. https://doi.org/10.1007/s10695-0119519-7

Shi, Z., Wang, H., Zhang, J., Xie, Y., Li, L. and Chen, X., 2005. Response of crayfish, Procambarus clarkii, haemocytes infected by white spot syndrome virus. J. Fish Dis., 28: 151-156. https://doi.org/10.1111/ j.1365-2761.2004.00607.x

Swain, P., Dash, S., Sahoo, P.K., Routray, P., Sahoo, S.K., Gupta, S.D., Meher, P.K. and Sarangi, N., 2007. Non-specific immune parameters of brood Indian major carp Labeo rohita and their seasonal variations. Fish Shellf. Immunol., 22: 38-43. https://doi.org/10.1016/j.fsi.2006.03.010

Tian, H.Y., Zhang, D.D., Li, X.F., Zhang, C.N., Qian, Y. and Liu, W.B., 2015. Optimum feeding frequency of juvenile blunt snout bream Megalobrama amblycephala. Aquaculture, 437: 60-66. https:// doi.org/10.1016/j.aquaculture.2014.11.032

Van Hulten, M.C.W., Witteveldt, J., Peters, S., Kloosterboer, N., Tarchini, R., Fiers, M., Sandbrink, H., Lankhorst, R.K. and Vlak, J.M., 2001. The white spot syndrome virus DNA genome sequence. Virology, 286: 7-22. https://doi.org/10.1006/ viro.2001.1002

Villarroel, M., Alavriño, J.M.R. and López-Luna, J., 2011. Effect of feeding frequency and one day fasting on tilapia (Oreochromis niloticus) and water quality. Isr. J. Aquacult. Bamid., 63: 609-615.
Wan, J.J., Shen, M.F., Tang, J.Q., Lin, H., Yan, W.H., Li, J.J. and Zhu, L., 2017. Effects of soybean meal processing treatments on growth performance, nutrient digestibility, nitrogen and phosphorus excretion in red swamp crayfish, Procambarus clarkia. Aquacul. Int., 25: 543-554. https://doi. org/10.1007/s10499-016-0052-7

Wang, C.Z., Li, Z., Liang, H.W., Hu, G.F. and Wu, Q.C., 2009. Genetic diversity in four Procambarus clarkii populations in the lower reaches of the Yangtze River. Biodiv. Sci., 17: 518-523.

Wang, N., Hayward, R.S. and Noltie, D.B., 1998. Effect of feeding frequency on food consumption, growth, size variation, and feeding pattern of age-0 hybrid sunfish. Aquaculture, 165: 261-267. https://doi. org/10.1016/S0044-8486(98)00266-X

Wang, Y., Kong, L.J., Li, K. and Bureau, D.P., 2007. Effects of feeding frequency and ration level on growth, feed utilization and nitrogen waste output of cuneate drum (Nibea miichthioides) reared in net pens. Aquaculture, 271: 350-356. https://doi. org/10.1016/j.aquaculture.2007.03.022

Xie, F.J., Ai, Q.H., Mai, K.S., Xu, W. and Ma, H.M., 2011. The optimal feeding frequency of large yellow croaker (Pseudosciaena crocea, Richardson) larvae. Aquaculture, 311: 162-167. https://doi. org/10.1016/j.aquaculture.2010.12.005

Xu, W.N., Liu, W.B., Shen, M.F., Li, G.F., Wang, Y. and Zhang, W.W., 2013. Effect of different dietary protein and lipid levels on growth performance, body composition of juvenile red swamp crayfish (Procambarus clarkii). Aquacul. Int., 21: 687-697. https://doi.org/10.1007/s10499-012-9603-8

Yearbook CFS., 2019. China Fishery Statistics Yearbook. Bureau of Fisheries, Ministry of Agriculture, Beijing, China.

Yi, S.K., Li, Y.H., Shi, L.L. and Zhang, L., 2017. Novel insights into antiviral gene regulation of red swamp crayfish, Procambarus clarkii, infected with white spot syndrome virus. Genes, 8: 320. https://doi. org/10.3390/genes 8110320

Yildiz, H.Y., 2006. Plasma lysozyme levels and secondary stress response in rainbow trout, Oncorhynchus mykiss (Walbaum) after exposure to Leteux-Meyer mixture. Turk. J. Anim. Sci., 30: 259-269.

Zeng, Y. and Lu, C.P., 2009. Identification of differentially expressed genes in haemocytes of the crayfish (Procambarus clarkii) infected with white spot syndrome virus by suppression subtractive hybridization and cDNA microarrays. Fish Shellf. Immunol., 26: 646-650. https://doi.org/10.1016/j. 
fsi.2008.11.005

Zhan, W., Wang, Y., Fryer, J.L., Yu, K., Fukuda, H. and Meng, Q., 1998. White spot syndrome virus infection of cultured shrimp in China. J. Aquat. Anim. Hlth., 10: 405-410. https://doi.org/10.1577/15488667(1998)010<0405:WSSVIO > 2.0.CO;2

Zhang, Y., Ning, J.F., Qu, X.Q., Meng, X.L. and Xu, J.P., 2012. TAT-mediated oral subunit vaccine against white spot syndrome virus in crayfish. $J$. Virol. Meth., 181: 59-67. https://doi.org/10.1016/j. jviromet.2012.01.011

Zhao, S., Han, D., Zhu, X., Jin, J., Yang, Y. and Xie,
S., 2016. Effects of feeding frequency and dietary protein levels on juvenile allogynogenetic gibel carp (Carassius auratus gibelio) var. CAS III: growth, feed utilization and serum free essential amino acids dynamics. Aquacul. Res., 47: 290-303. https://doi. org/10.1111/are.12491

Zhou, Z., Cui, Y., Xie, S.Q., Zhu, X., Lei, W., Xue, M. and Yang, Y., 2003. Effect of feeding frequency on growth, feed utilization, and size variation of juvenile gibel carp (Carassius auratus gibelio). J. appl. Ichthyol., 19: 244-249. https://doi.org/10.1046/ j.1439-0426.2003.00453.x 